is known about the part played by physical disability in the causation of accidents that it is unlikely that many more licences will be refused than at present. As the body of information accumulates from the scheme it should be possible to correlate accident rates with diagnostic categories, and in time a policy could be developed which is supported by reliable scientific evidence.

\section{Treatment of Oral Cancer}

During the past 30 years deaths from cancer of the mouth have steadily declined. ${ }^{1}$ This has been mainly due to a falling incidence of the disease, but earlier diagnosis and improved methods of treatment have also been responsible. The disease usually remains localized to the primary site and its lymph drainage areas; so it can be controlled by effective treatment, but a close liaison between surgeons and radiotherapists is of the greatest importance in achieving the best results.

The place of surgery and radiotherapy has been debated for many years. At many centres a combined method has been favoured in which radiotherapy to the primary tumour is followed by a block dissection of the neck for palpable nodes. Some therapists ${ }^{2}$ have treated by radiotherapy both the primary growth and any enlarged nodes which may present.

After the war there was a revival of interest in the treatment of oral cancer by more radical surgical techniques, particularly for the more advanced tumours. The method employed combines a resection of the primary growth with a radical dissection of the neck and removal of the intervening structures in continuity-the so-called "commando" operation. The results of 227 cases treated in this way have been published ${ }^{3}$ from the Memorial Hospital, New York; five-year survival rates of $30 \%$ were obtained in patients who had either large local tumours or in whom the growth had spread to the cervical nodes.

In the same period improved methods of radiation treatment were also introduced, particularly the use of high energy radiations from cobalt units and linear accelerators, and again better survival rates than were possible with the older forms of treatment have been reported." Comparison of the results in the published series is difficult because of selection in the various groups. D. P. Shedd and his colleagues ${ }^{5}$ in a tenyear survey of oral cancer at the Yale New Haven Hospital concluded that in cancer of the tongue there was a fair possibility of cure by irradiation, surgery, or both. Similarly G. S. Sharp and J. T. Helsper ${ }^{6}$ were unable to show that either method was better. Though the cure rates seem to be about the same, the high morbidity of the surgical pro-

\footnotetext{
- Registrar General's Annual Statistical Review of England and $W$ ales for 1937 and 1966, 1938 and 1967. H.M.S.O., London.

Wood, C. A. P., and Boag, J. W., Spec. Rep. Ser. med. Res. Coun.

(Lond.), 1950, No. 267.

- Fletcher, G. H., and MacComb, W. S., Radiation Therapy in Management of Cancer of the Oral Cavity and Oropharynx, 1962. Springfield, Ill.

- Shedd, D. P., Von Essen, C. F., Bevin, A. G., and Greenberg, R. A., Amer. F. Surg., 1967, 114, 844 .

- Sharp, G. S., and Helsper, J. T., Amer. F. Surg., 1964, 108, 456.

- Cade, S., and Lee, E. S., Brit. f.' Surg., 1957, 44, 433.

- Arthur, J. F., and Fenner, M. L.. Clin. Radiol., 1966, 17, 384.

- Burn, J. I., Johnston, I. D. A., Davies, A. J., and Sellwood, R. A., Brit. f. Surg., 1966, 53, 329.

10 Friedman, M., and Daly, J. F., Amer. F. Roentgenol., 1963, 90, 246

11 Berry, R. J., Amer. F. Roentgenol., 1968, 102, 509.

12 Gray, L. H., Amer. 7. Roentgenol., 1968, 102, 509. O. C. A., Brit. F. Radiol., 1953, 26, 638.
}

cedure may be a deciding factor in the choice of treatment. Complete clearance of the tumour often implies mutilation, and though the patient is cured of the disease he may be unacceptable socially and incapable of earning a living, ${ }^{7}$ because of the difficulties with speech and swallowing. So radiotherapy is still the method of choice for the primary growth, except in the case of small tumours for which a limited operation can be done. Block dissection remains the treatment of choice for enlarged nodes that are mobile, but when these are not palpable a careful watching policy is to be preferred to immediate operation. The extensive "commando" procedure is probably best reserved for special situations such as when the mandible is extensively invaded or when the disease has recurred.

The influence of the histological grading of the tumour on the survival rate was investigated by J. F. Arthur and M. L. Fenner. ${ }^{8}$ Their system of grading was based on keratinization, mitotic activity, and cell irregularity and they showed a correlation between the grading and survival rate. Their results also suggested that surgery gave better results than radiotherapy in the treatment of nodes from differentiated tumours but the converse was true for undifferentiated tumours.

Newer methods of treatment are still under trial but have not yet been fully assessed. Chemotherapy alone is seldom curative $^{9}$ but it may be a helpful adjunct to either surgery or radiotherapy. M. Friedman and J. F. Daly ${ }^{10}$ were able to show improved results when oral methotrexate was given during radiation treatment, and direct infusion of methotrexate into the artery supplying the tumour has recently given some promising results when given prior to radiation treatment. Experiments by R. J. Berry ${ }^{11}$ on the effect of $x$ rays and methotrexate on human tumour cells grown in vitro suggest that the most effective combination is a course of radiotherapy given ih a small number of large fractions and each preceded by the highest tolerated dose of methotrexate.

There is also experin:ental evidence to suggest that densely ionizing radiation such as neutrons may be a more effective form of radiotherapy than the conventional types. ${ }^{12}$ A trial of this form of treatment, which requires an elaborate and expensive installation, is currently being conducted, using a cyclotron generator, at Hammersmith Hospital.

\section{Psychiatry for General Practitioners}

It is paradoxical that the branch of medicine which occupies more of the time of a general practitioner than any other should be the one for which he is worst trained. Until ten years ago psychiatry was a minor part of the undergraduate curriculum, and many established doctors are acutely aware of the deficiencies in their knowledge in this specialty.

Starting this week the B.M.f. is publishing in the Current Practice section a series of articles on psychiatry in general practice. The articles are not concerned with theory or with clinical rarities; they aim to give practical advice on the management of common disorders. Suggestions for further reading will be given during the series. Much satisfaction can be gained from helping patients with their psychiatric problems. We hope these articles will help more general practitioners to find it. 